\title{
Effect of Organic Manures and Weed Management Practices on Yield Attributes and Soil Enzyme Activities of Winter Irrigated Cotton
}

\author{
S. Marimuthu* and M. Mohamed Amanullah \\ Department of Agronomy, Tamil Nadu Agricultural University, Coimbatore - 641 003, India \\ *Corresponding author
}

\author{
A B S T R A C T
}

\section{Keywords}

Composted poultry

manure, Hand

weeding, Boll

weight, Soil

enzymes.

\section{Article Info}

Accepted:

18 February 2017

Available Online:

10 March 2017
Field experiment was conducted on a sandy loam soil during winter irrigated season of 2015-16 at Department of Farm Management, Tamil Nadu Agricultural University, Coimbatore to study the effect of various organic manures and weed control methods on yield attributes and soil enzyme activities of organic cotton cultivation. The experiment was laid out in strip plot design and replicated thrice. Treatments viz., farmyard manure, vermicompost, goat manure and composted poultry manure were assigned to main plot; while hand weeding, twin wheel hoe weeding, power weeding and weedy check were assigned to sub plot and replicated thrice. Weeding operations were done at 20 and 40 DAS. The results of this study showed that organic sources of nutrient and weed management practices, especially composted poultry manure and hand weeding at 20 and 40 DAS enhanced sympodial branches (19.52), fruiting points (54.24), number of bolls (20.65) and boll weight $(4.71 \mathrm{~g})$ which was comparable with application of composted poultry manure with power operated weeder weeding on 20 and 40 DAS. Significantly higher enzymes activities viz., phosphatase $\left(39.15 \mu \mathrm{g}\right.$ of p-nitrophenol released $\left.\mathrm{g}^{-1} \mathrm{soil} \mathrm{h}^{-1}\right)$, dehydrogenase $\left(6.47 \mu \mathrm{g}\right.$ of TPF released $\mathrm{g}^{-1}$ soil h$\left.{ }^{-1}\right)$ and urease $\left(44.41 \mu \mathrm{g} \mathrm{NH}_{4}^{+} \mathrm{g}^{-1}\right.$ soil h$\left.{ }^{-1}\right)$ were found in treatment of composted poultry manure along with hand weeding or power weeding twice on 20 and 40 DAS at harvesting stage. Based on the results, it can be concluded that composted poultry manure along with hand weeding or power weeder weeding in order to enhances soil organic carbon and microbial activity/diversity, which subsequently improve soil enzyme synthesis provide nutrients for crop growth and yield of organic cotton cultivation.

\section{Introduction}

Cotton, also known as 'white gold', dominates India's cash crops, and makes up 65 per cent of the raw material requirements of the Indian textile industry. Cotton is a very important cash crop for smallholder farmers, but also one of the most exigent crops in terms of agrochemical inputs which are responsible for adverse effects on human health and the environment (Forster et al., 2013). One of the major concerns in today's world is the pollution and contamination of the soil. The use of chemical fertilizers and pesticides has caused tremendous harm to the environmental ecosystem. Organic farming or natural farming is necessary to support the developing organic, sustainable and nonpollution agriculture. These methods are cost effective and ecofriendly in nature (Narasimha, 2013). The most of the cotton cultivated in India is 'ecofriendly' with little 
or no use of toxic chemicals in its production. Since people in advanced countries are very much health conscious, they demand for readymade cloths produced from certified organically grown cotton. But, maintaining soil fertility and soil productivity plays important role for sustainable production of organic cotton. Therefore, the need of the hour is to popularize environmental friendly and cost effective organic manures, which are produced in the farm by the farmer himself (Drakshayanimath et al., 2004).

Weed control and soil fertility are the principal challenges associated with organic cotton production. Weeds are responsible for heavy seed yield losses in cotton, even to the extent of complete crop loss under extreme conditions (Bahadur et al., 2015). Weed control in organic systems focuses on management technique designed to prevent weeds, as well as the production of crop with vigorous nature, enough to out-compete weeds and reduce the availability of resources to the weeds. The main target of weed management in organic farming is to reduce the degree of direct control inputs and to bring about substantial yield improvement of the crop (Basavaraj et al., 2013). Manual weeding is the most common practice in organic agriculture. It is still a practical and efficient method of eliminating weeds particularly annual and biennial weeds in cropped and non-cropped situations (Dubey, 2014). Nowadays, use of mechanical weeders in agricultural operations is increasing because of non-availability of labours for weeding. The cost of the weeding operations is also reduced by using the machineries for weeding (Bond and Grundy, 2001). The physiological demand in using weeders was relatively higher than in manual weeding. However the efficiency of the work in terms of area covered was significantly better with the weeder than with other weed control methods (Rajasekar, 2002).
Soil is an excellent natural medium and soil enzymes play key biochemical functions in the overall process of organic matter decomposition in the soil system. All biochemical reactions are dependent or related to enzymes present in the environment. The same applies for those processes which take place in soils (Yao et al., 2006). Based on their origin and development, soil types differ in organic matter content, soil organism composition and activity. In the intensity of the biological processes and soil enzymes the activity of soil enzymes is important for nutrient availability to the plants (Mehra, 2006). The enzyme is a substance composed of protein that is capable of lowering the activation energy of selected other compound enough to allow the breaking of particular bond under a particular environment, such enzymes which influence the reaction are called biological action Soil enzymes activity may provide useful index of changes in soil quality (Nannipieri et al., 2004). Enzymes play key roles in the cycling of nutrients in nature and their activity is sensitive to agricultural practices and considered as an index of soil fertility In the light of the above facts, the experiment was laid out for the better understanding of yield attributes and soil enzyme activities as influenced by various sources of organic manures and weed control methods in winter irrigated cotton.

\section{Materials and Methods}

The present trial was aimed to study the influence of various organic manures and weed management practices on yield attributes and soil enzyme activities of organic cotton cultivation. The field experiment was carried out at Eastern Block, Department of Farm Management, Tamil Nadu Agricultural University, Coimbatore during winter irrigated season (August) 201516. The soil of the experimental field was 
sandy clay loam in texture belonging to Typic Ustropept with the initial analysis of the soil of the experimental site revealed that soil was slightly alkaline ( $\mathrm{pH}$ : 7.8) with low soluble salts (EC: $0.32 \mathrm{dSm}^{-1}$ ), low in available nitrogen (192 kg/ha), low in available phosphorus (17.2 kg/ha) and high in available potassium $(520 \mathrm{~kg} / \mathrm{ha})$. The treatments of organic manures viz., farmyard manure, vermicompost, goat manure and composted poultry manure were assigned to main plot and weed management practices viz., hand weeding, twin wheel hoe weeding, power weeder weeding and weedy check were fitted in the subplot.

All the weeding operations were given on 20 and 40 DAS. The inter row weeds in machine or implements operated plots of inter row were removed manually. Organic manures on equal nitrogen basis were applied to respective plots as per treatment of organic manure viz. Farmyard manure (16 t/ha), vermicompost $(5.23 \mathrm{t} / \mathrm{ha})$, goat manure $(6.15$ t/ha) and composted poultry manure (3.63 t/ha). In order to maintain uniformity in plant population, the seeds of cotton (var. suraj) were treated with Bacillus subtilis and dibbled in respective treatment plots adopting $75 \mathrm{~cm} \times$ $30 \mathrm{~cm}$ spacing at 1 to 2 seeds/hole. After germination, seedlings were thinned to one plant per stand three weeks after sowing. Five plants were tagged at random in each treatment plot for recording the various growth and yield attributes of cotton crop.

\section{Assessment of enzyme activity}

The enzyme activity was determined at initial and post-harvest stages of cotton. The substrates and methods followed for enzyme assays as shown in table 1 . The data recorded on various parameters during the cropping period which were statistically analysed following the analysis of variance as suggested by Gomez and Gomez (2010). Wherever the treatmental differences were found significant (' $F$ ' test), critical difference was worked out at 0.05 probability level.

\section{Results and Discussion}

Yield is a complex trait and is influenced by many factors. Cotton yield is determined by the number of yield contributing factor such as number of sympodia, number of fruiting points, number of bolls, and number of bolls were significantly influenced by organic manures and weed management practices.

\section{Symbodial branches}

Among the various sources of organic manures, 100 per cent RDN through composted poultry manure was recorded symbodial branches of 17.77 branches/plant which was comparable with application of 100 per cent RDN through goat manure (Table 2), the reasons for more number of sympodial branches was attributed to increased soil organic carbon and higher concentration of available nutrients through composted poultry manure. This had positive effect on sympodial branches, which resulted in increased the top growth of the plant and more number of nodes which are the seating points for the sympodial branches (Solaiappan, 2002).

With regards, weed management practices, more symbodial branches (18.37 branches/ plant) were recorded with hand weeding at 20 and 40 DAS followed by power weeder weeding at 20 and 40 DAS. This might be due to reduced weeds and competition free environment at the critical stages of crop favoured the crop to utilize the growth factors and improves effectively leading to the production of more sympodial branches compared to all other treatments and responsible for higher yield. Similarly, hand weeding or power weeding at 25 and 45 DAS was effective weed control method for cotton as observed by Nithya and Chinnusamy (2013). 


\section{Fruiting points}

With concerns the organic manures, more number of fruiting points (46.86) was observed with application of 100 per cent RDN through composted poultry manure followed by 100 per cent RDN through goat manure applied plots (Table 2). The fruiting points are the key source for assessing the yield efficiency of the cotton plants. Higher leaf area, types of leaves play a major role in production of more photosynthates which has a direct link with fruiting points. $\mathrm{N}$ nutrition has a direct bearing on growth and consequently, improves the number of fruiting points (Kerby and Buxton, 1976).

Among the weed control methods, hand weeding twice at 20 and 40 DAS recorded higher number of fruiting points (50.07) which was comparable with power weeder weeding at 20 and 40 DAS. It might be due to the decreased weed competition and minimized nutrient removal by weeds provided a competition free environment for the crop for better growth and development. This had increased the capacity of the crops to take nutrients especially NPK and enhanced assimilation sources viz., LAI, DMP and well balanced source sink relationship which in turn increased the more number of fruiting points in cotton. The results were in agreement with the findings of Sureshkumar, (2014).

\section{Number of bolls and boll weight}

Boll formation is very much influenced by nutrient supply and weed control methods that prevailed during the crop growth period (Table 2). From this study, it was observed that more number of bolls (17.22) and boll weight (4.20) were recorded 100 per cent RDN through composted poultry manure followed by application of 100 per cent RDN through goat manure.

Adequate nutrient availability under organic manures at critical stages influenced the boll setting percentage and number of bolls. Organic sources play a key role in enhancing efficient utilization of the native as well as applied nutrient through matching nutrient availability with crop requirement to exhibit crop's productive capability. These organic sources also supply some micronutrients and growth promoting substances, which might have helped in higher boll retention and seed cotton yield (Drakshayanimath et al., 2004).

Table.1 Standard methods followed for soil enzyme analysis

\begin{tabular}{|c|l|l|l|}
\hline \multicolumn{1}{|c|}{ Enzyme } & \multicolumn{1}{|c|}{ Substrate } & \multicolumn{1}{c|}{ Methods } & \multicolumn{1}{c|}{ Reference } \\
\hline Urease & $\begin{array}{l}\text { Urea solution } \\
(10 \%)\end{array}$ & $\begin{array}{l}\text { Using spectro photometer } \\
\text { at } 630 \mathrm{~nm}\end{array}$ & $\begin{array}{l}\text { Tabatabai and } \\
\text { Bremner (1969) }\end{array}$ \\
\hline Dehydrogenase & $\begin{array}{l}\text { 2,3,5-Triphenyl } \\
\text { tetra azolium } \\
\text { chloride }\end{array}$ & $\begin{array}{l}\text { Titrated against 0.025 m } \\
\text { potassium permanganate } \\
\text { till pink colour appears }\end{array}$ & Casida et al (1964) \\
\hline Phosphatase & $\begin{array}{l}\text { p-nitro phenol } \\
\text { phosphate }\end{array}$ & $\begin{array}{l}\text { Using spectrophotometer } \\
\text { at 420 nm }\end{array}$ & Halstead (1964) \\
\hline
\end{tabular}


Table.2 Effect of organic manures and weed management practices on yield attributes at 120 DAS of cotton

\begin{tabular}{|c|c|c|c|c|c|c|c|c|c|c|}
\hline \multirow{2}{*}{ Treatment } & \multicolumn{5}{|c|}{ Sympodial branches (No/plant) } & \multicolumn{5}{|c|}{ No. of fruiting points (No/plant) } \\
\hline & $\mathbf{W}_{1}$ & $\mathbf{W}_{2}$ & $\mathbf{W}_{3}$ & $\mathbf{W}_{4}$ & Mean & $\mathbf{W}_{1}$ & $\mathbf{W}_{2}$ & $\mathbf{W}_{3}$ & $\mathbf{W}_{4}$ & Mean \\
\hline $\mathbf{N}_{1}$ & 16.57 & 10.53 & 15.18 & 9.74 & 13.00 & 41.66 & 35.29 & 41.57 & 29.94 & 37.11 \\
\hline $\mathbf{N}_{2}$ & 18.32 & 13.48 & 17.15 & 10.29 & 14.81 & 52.51 & 34.91 & 45.89 & 33.81 & 41.78 \\
\hline $\mathbf{N}_{3}$ & 19.06 & 16.74 & 18.80 & 13.66 & 17.07 & 51.87 & 42.02 & 43.03 & 34.42 & 42.83 \\
\hline $\mathbf{N}_{4}$ & 19.52 & 17.11 & 19.33 & 15.14 & 17.77 & 54.24 & 48.67 & 50.06 & 34.46 & 46.86 \\
\hline \multirow[t]{2}{*}{ Mean } & 18.37 & 14.47 & 17.62 & 12.21 & & 50.07 & 40.22 & 45.14 & 33.16 & \\
\hline & $\mathbf{N}$ & $\mathbf{W}$ & $\mathbf{N}$ at $\mathbf{W}$ & $\mathrm{W}$ at $\mathbf{N}$ & & $\mathbf{N}$ & $\mathbf{W}$ & $\mathbf{N}$ at $\mathbf{W}$ & $\mathbf{W}$ at $\mathbf{N}$ & \\
\hline SEd & 0.63 & 0.50 & 0.96 & 0.88 & & 1.20 & 1.04 & 2.15 & 1.94 & \\
\hline $\begin{array}{c}\text { CD } \\
(\mathbf{P}=\mathbf{0 . 0 5})\end{array}$ & 0.54 & 1.22 & 2.16 & 1.94 & & 2.94 & 2.65 & 4.75 & 4.27 & \\
\hline \multirow{2}{*}{ Treatment } & \multicolumn{5}{|c|}{ No. of bolls/plant } & \multicolumn{5}{|c|}{ Boll weight (g) } \\
\hline & $\mathbf{W}_{1}$ & $\mathbf{W}_{2}$ & $\mathbf{W}_{3}$ & $\mathbf{W}_{4}$ & Mean & $\mathbf{W}_{1}$ & $\mathbf{W}_{2}$ & $\mathbf{W}_{3}$ & $\mathbf{W}_{4}$ & Mean \\
\hline $\mathbf{N}_{1}$ & 15.01 & 12.22 & 14.86 & 9.79 & 12.97 & 4.32 & 3.37 & 3.70 & 2.53 & 3.48 \\
\hline $\mathbf{N}_{2}$ & 19.07 & 12.42 & 16.60 & 11.14 & 14.81 & 4.50 & 3.36 & 4.25 & 2.89 & 3.75 \\
\hline $\mathbf{N}_{3}$ & 19.19 & 15.41 & 16.01 & 11.59 & 15.55 & 4.61 & 3.98 & 4.49 & 3.08 & 4.04 \\
\hline $\mathbf{N}_{4}$ & 20.65 & 17.44 & 18.96 & 11.83 & 17.22 & 4.71 & 4.36 & 4.57 & 3.16 & 4.20 \\
\hline \multirow[t]{2}{*}{ Mean } & 18.48 & 14.37 & 16.61 & 11.09 & & 4.53 & 3.77 & 4.25 & 2.92 & \\
\hline & $\mathbf{N}$ & $\mathbf{W}$ & $\mathbf{N}$ at $\mathbf{W}$ & $\mathbf{W}$ at $\mathbf{N}$ & & $\mathbf{N}$ & $\mathbf{W}$ & $\mathbf{N}$ at $\mathbf{W}$ & $\mathbf{W}$ at $\mathbf{N}$ & \\
\hline SEd & 0.77 & 0.72 & 1.14 & 1.01 & & 0.14 & 0.16 & 0.30 & 0.31 & \\
\hline $\begin{array}{c}\text { CD } \\
(\mathbf{P}=\mathbf{0 . 0 5})\end{array}$ & 1.87 & 1.80 & 2.57 & 2.34 & & 0.34 & 0.38 & NS & NS & \\
\hline
\end{tabular}

$\mathrm{N}_{1}: 100 \% \mathrm{RDN}$ through Farmyard manure

$\mathrm{N}_{2}: 100 \%$ RDN through vermicompost

$\mathrm{N}_{3}: 100 \%$ RDN through goat manure

$\mathrm{N}_{4}: 100 \% \mathrm{RDN}$ through composted poultry manure
$\mathrm{W}_{1}$ : Hand weeding at 20 and 40 DAS

$\mathrm{W}_{2}$ : Twin wheel hoe weeder weeding at 20 and 40 DAS

$\mathrm{W}_{3}$ : Power weeder weeding at 20 and 40 DAS

$\mathrm{W}_{4}$ : Weedy check 
Figure.1 Effect of organic manures and weed control methods on soil dehydrogenase activity of cotton

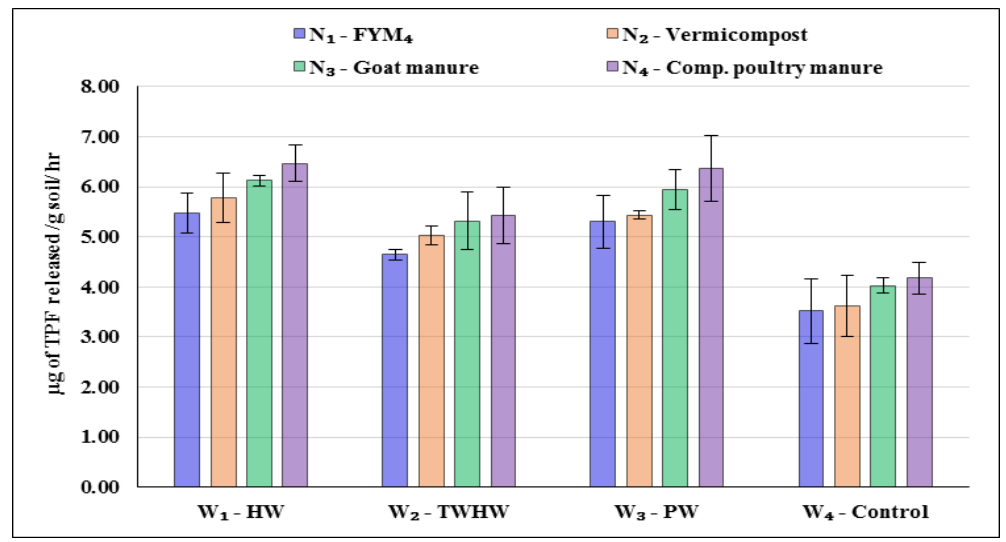

Figure.2 Effect of organic manures and weed management practices on soil urease activity in cotton

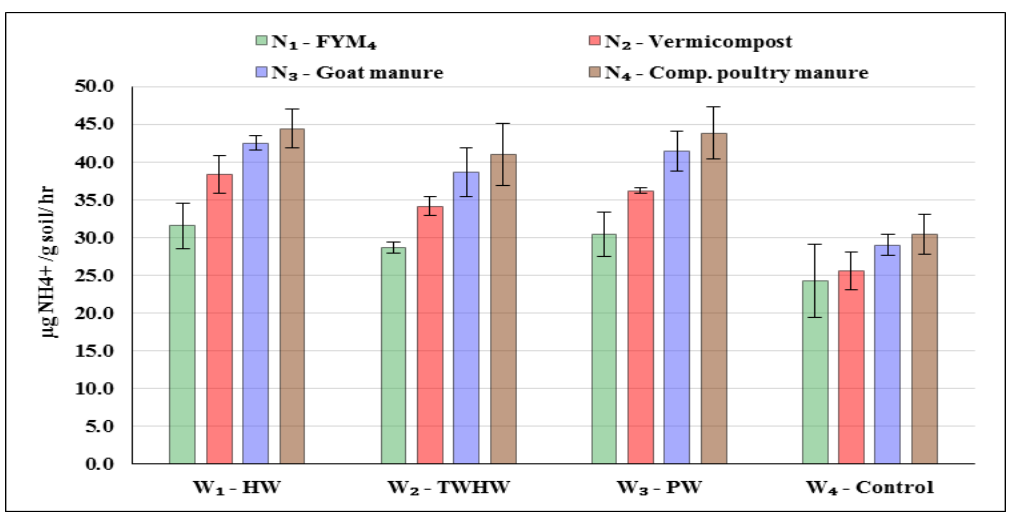

Figure.3 Effect of organic manures and weed control methods on soil phosphatase activity of cotton

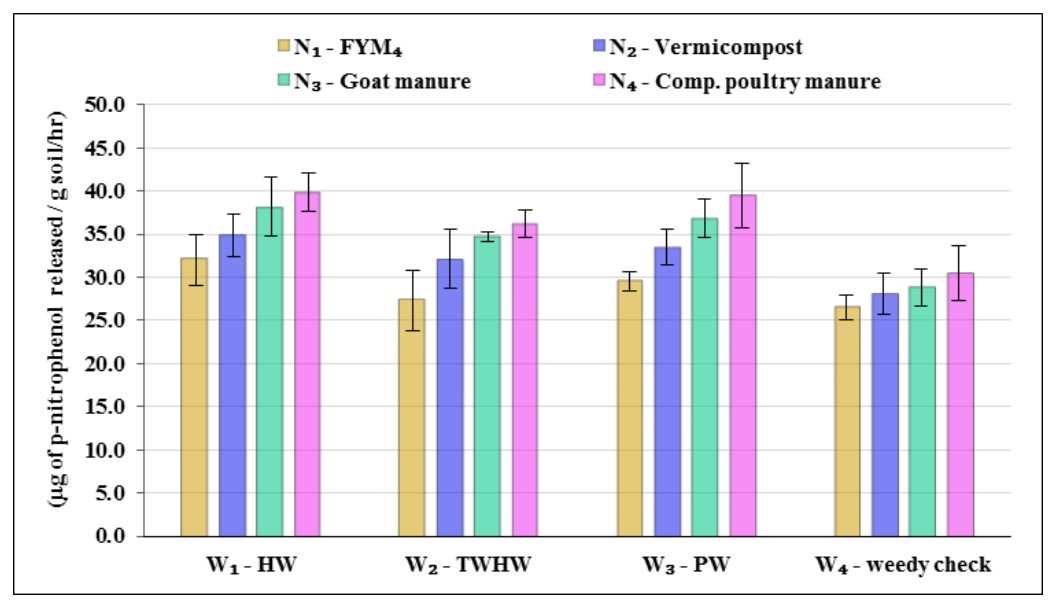


Regarding weed management practices, hand weeding at 20 and 40 DAS was recorded more number of bolls (18.48) and higher weight of bolls (4.53) followed by application of power weeder weeding at 20 and 40 DAS. The weed control treatments reduced the weed density and weed dry matter as compared to weedy check resulting in more nutrients available to the crop for uptake resulted in better growth and production of cotton bolls. The results are in confirmation with the findings of Raskar and Bhoj (2002) who have recorded higher seed cotton yield with two hand weeding compared to other herbicidal methods of weed control.

The interaction between organic manures and weed management practices were significantly recorded more number of sympodial branches (19.52), fruiting points (54.24), number of bolls (20.65) and boll weight $(4.71 \mathrm{~g})$ found in treatment of 100 per cent RDN composted poultry manure along with hand weeding at 20 and 40 DAS followed by 100 per cent RDN composted poultry manure with power weeding at 20 and 40 DAS were provided a weed free situation by timely control of weeds during the critical period of crop weed competition in cotton. This might be due to better control of all categories of weeds. These might have resulted in better interception, absorption and utilization of radiation energy leading to higher photosynthetic rate finally more accumulation of dry matter by the plant. The overall improvement of crop growth reflected into better source- sink relationship, which in turn enhanced the yield attributes. The results are analogous to those reported by Geetha and Kathiresan (2006) and Shaikh et al., (2010).

\section{Soil enzyme activity}

The influence of organic sources of nutrients and weed control methods on the soil microbial population, the fluctuation in the microbial loading the soil is based on the availability of carbon source in the soil and enhanced microbial and enzyme activity stimulated by organic manures (Qiong et al., 2014).

\section{Soil dehydrogenase activity}

The activity of the enzyme dehydrogenase ( $\mu \mathrm{g}$ of TPF released $\mathrm{g}^{-1}$ soil $\mathrm{h}^{-1}$ ) was found to be strongly and consistently influenced by different organic manures applied plots (Figure 1). Application of 100 percent RDN through composted poultry manure with two hand weeding at 20 and 40 DAS found to be superior in the removal of hydrogen by accounting the highest activity value of 6.47 $\mu \mathrm{g}$ of TPF released $\mathrm{g}^{-1}$ soil $\mathrm{h}^{-1}$ which was comparable with 100 per cent RDN through poultry manure with power weeding at 20 and 40 DAS had similar influence in the activity of dehydrogenase at harvest stage. The high organic carbon content in soil applied with composted poultry manure have stimulated the microorganisms by serving as source of carbon, energy and other nutrients essential for their growth and multiplication and thus increased the soil enzyme activities (Boomiraj, 2003).

\section{Urease activity}

The urease activity was found to be influenced by different organic and weed management practices during winter irrigated season 2015-16, the urease activity (44.41 $\mu \mathrm{g}$ $\mathrm{NH}_{4}^{+} \mathrm{g}^{-1}$ soil $\mathrm{h}^{-1}$ ) was higher with the application of 100 percent RDN poultry manure along with hand weeding twice at 20 and 40 DAS and it was comparable with 100 per cent RDN through poultry manure with power weeding at 20 and 40 DAS (Figure 2). The increase in enzyme activity in soils amended with organic manures is due to the stimulation of microbial activity rather than to the direct addition of enzymes from the organic sources (Nagavani and Subbian, 2014). Besides, increased levels of 
accumulated enzymes in the soil matrix and more importantly, direct contribution of enzymes by the organic manures themselves, might also be responsible for greater soil enzyme activity.

\section{Soil phosphatase activity}

The activity of the enzyme phosphatase was evaluated in terms of $\mu \mathrm{g}$ of p-nitrophenol released $\mathrm{g}^{-1}$ soil per hour. The enzyme phosphatase activity was found to be significantly influenced by all the nutrient and weed management practices (Figure 3). Application of 100 per cent RDN through composted poultry manure along with hand weeding twice at 20 and 40 DAS registered higher phosphatase activity of $39.15 \mu \mathrm{g}$ of $\mathrm{p}$ nitrophenol released $\mathrm{g}^{-1}$ soil $^{-1}$ it was on par with 100 per cent RDN goat manure with two power weeder weeding at 20 and 40 DAS. The increase in phosphatase with application of composted poultry compared to other organic manures is attributed to higher content of organic matter and enhanced microbial activity. The positive effect of composted poultry manure addition on enzyme activities has been demonstrated in several studies (Nagavani and Subbian, 2014). The various biochemical processes associated with nutrient recycling are mediated by soil enzymes which are derived from soil microbes and plant roots.

In conclusion, the results of the experiment showed that the use of composted poultry manure and two hand weedings or power weeding at 20 and 40 DAS might be the best option to enhances soil organic carbon status and microbial activity/diversity, which subsequently enhance soil enzyme synthesis and accumulation. This in turn would bolster the soil's capability to cycle and provide nutrients for crop growth and which found to be optimum for improving cotton production for promoting organic cotton cultivation.

\section{References}

Bahadur, S., S.K. Verma, S.K. Prasad, A.J. Madane, S.P. Maurya Gaurav, V.K. Verma and S.K. Sihag. 2015. Ecofriendly weed management for sustainable crop production - A Review. J. Crop and Weed, 11(1): 181-189.

Basavaraj, P., V.C. Reddy, T.V. Ramachandra Prasad, B.C. Shankaralingappa, R. Devendra and K.N. Kalyanamurthy. 2013. Weed management in irrigated organic finger millet. Indian J. Weed Sci., 45(2): 143-145.

Bond, W. and A.C. Grundy. 2001. Non chemical weed management in organic farming systems. Weed Res., 41(5): 383405.

Boomiraj, K. 2003. Evaluation of organic sources of nutrient, panchagavya and botanicals spray on bhendi (Abelmoschus esculentus Moench). M.Sc., Thesis. Tamil Nadu Agricultural University, Coimbatore, India.

Casida, J., L.E., D.A. Klein and T. Santoro, 1964. Soil dehydrogenase activity. Soil Sci., 98(6): 371-376.

Drakshayanimath, M., Shekaragouda and M. B. Kurdikeri. 2004. Effect of organic manures, pesticides and bio-pesticides on seed yield and quality in G. hirsutum c.v. Sahana. In: International symposium on "Sustainable Cotton Production - A Global Vision" 1. Crop Improvement, pp: 335-339.

Dubey, R.P. 2014. Integrated weed management- an approach. In Training Manual Advance Training in Weed Management, held at DWSR, Jabalpur, India on 14-23 January, pp. 19-21.

Forster, D., C. Andres, R. Verma, C. Zundel, M.M. Messmer and P. Mader. 2013. Yield and economic performance of organic and conventional cotton-based farming systems results from a field trial in India. PLoS ONE, 8(12): 81039. doi:10.1371/journal.pone.0081039.

Geetha, J. and R.M. Kathiresan. 2006. Influence of organic manures on the weed seed 
bank in maize. Indian $J$. Weed Sci., 38(1\&2): 247-249.

Gomez, K.A. and A.A. Gomez. 2010. Statistical Procedures for Agricultural Research $\left(2^{\text {nd }}\right.$ ed), John Wiley and Sons, New York, U.S.A.

Halstead, R.L. 1964. Phosphatase activity of soils as influenced by lime and other treatments, Canadian J. Soil Sci., 44(1): 137-144.

Kerby, T.A. and D.R. Buxton. 1976. Fruiting in cotton as affected by leaf type and planting density. Belt wide Cotton Production Res. Conf. Proc. National Cotton Council Memphis, Tenn. P. 67-70.

Kumar, S., N.N. Angiras Rana, S.S. Thakur and S. Aravind. 2008. Evaluation of doses of some herbicides to manage weeds in soybean (Glysine max L.). Indian J. Weed Sci., 40(1): 56-61.

Mehra, R.K. 2006. Textbook of Soil Science, ICAR Publication, $\left(2^{\text {nd }}\right.$ ed). New Delhi, pp: 401-421.

Nagavani, A.V. and P. Subbian. 2014. Influence of integrated nutrient management on soil enzymatic activity in hybrid maize. Curr. Biotica, 7(4): 314-317.

Nannipieri, P., E. Kandeler and P. Ruggiero. 2002. Enzyme activities and microbiological and biochemical processes in soil. In: Burns, R.G. and R.P. Dick (eds). Enzymes in the environment: activity, ecology and applications. Marcel Dekker, New York, USA.

Narasimha, G. 2013. Impact of organic manure amendment on soil physicochemical, biological and enzymatic properties, BTAIJ, 7(4): 154-158.

Nithya, C. and C. Chinnusamy. 2013. Evaluation of weed control efficacy and seed cotton yield in transgenic cotton Indian J. Applied Res., 3(6):10-12.

Qiong, L., H. Chen, Y. Gong, H. Yang, M. Fan and Y. Kuzyakov. 2014. Effects of 15 years of manure and mineral fertilizers on enzyme activities in particle-size fractions in a North China Plain soil. European J. Soil Biol., 60: 112-119.

Rajasekar, S. 2002. Design, development and performance of tractor drawn multirow rotary weeder. M.E (Ag.) Thesis. Tamil Nadu Agricultural University, Coimbatore.

Raskar, B.S. and P.G. Bhoj. 2002. Bio-efficacy of Mon 77569 and glyphosate for control of weeds in cotton. Indian J. Weed Sci., 34: 241-242.

Shaikh, A.A., M.M. Desai, S.B. Shinde and R.S. Kamble. 2010. Yield and quality of soybean (Glycine $\max$ L.) Merrill) as influenced by integrated weed management. Int. J. Agric. Sci., 6(2): 534536.

Solaiappan, U. 2002. Effect of inorganic fertilizer and organic manure on cottonsorghum rotation in rainfed Vertisols, Madras Agric. J., 89(7-9): 448-450.

Sureshkumar, K. 2014. Integrated weed management in hybrid brinjal, M.Sc., Thesis, Agricultural College and Research Institute, Tamil Nadu Agricultural University, Madurai.

Tabatabai, M.A. and M.J. Bremner. 1969. Use of $p$-nitrophenol phosphate for assay of soil phosphatase activity. Soil Biol. Biochem., 1(4): 301-307.

Yao, X.H., M. Huang, Z.H. Lu and H.P. Yuan. 2006. Influence of acetamiprid on soil enzymatic activities and respiration. European J. Soil Biol., 42: 120-126.

\section{How to cite this article:}

Marimuthu, S. and Mohamed Amanullah, M. 2017. Effect of Organic Manures and Weed Management Practices on Yield Attributes and Soil Enzyme Activities of Winter Irrigated Cotton. Int.J.Curr.Microbiol.App.Sci. 6(3): 1058-1066. doi: https://doi.org/10.20546/ijcmas.2017.603.122 